\title{
Developing agency through music and movement
}

\author{
Abstract \\ This ethnographic study examines the development of agency in students with special needs during \\ an experiment of classroom music teaching in a special school. The experiment took place from
}


August 2015 to March 2016 and was based on Emile Jaques-Dalcroze's ideas of music and movement as a means of developing competencies, skills and understanding in music and life in general. The lessons included activities, such as quick reaction and follow exercises, singing with movement, body percussion exercises, dancing, movement improvisation, and relaxation exercises. The data consisted of video recordings of the lessons, and interviews with students, teachers, and teaching assistants. The data was analyzed using qualitative analysis software and thematic analysis. The analysis of the ethnographic data of this practitioner research showed that music-andmovement activities support the development of students' agency by fostering a) students' own decision-making, b) interaction with others, c) expression of emotions and initiative, and d) being recognized by others as active and able musicians. Consequently, this study encourages educators to advocate music and movement as a tool to support individual agency and active participation in and outside the classroom.

Keywords: agency, music and movement, music education, special needs

\section{Introduction}

In Finland, an important objective of basic education is to support individuals' "growth into humanity and into ethically responsible membership of society" (Basic Education Act 628/1998). The latest Finnish National Core Curriculum for Basic Education (2014) has underlined the importance of involving students in decision-making. However, statements in curricula do not guarantee all students' full participation in and after basic education. The making of educational and vocational choices might be affected by impaired social, mental or physical abilities. Davis and Watson's study (2000) shows that disabled pupils are often denied agency in educational situations, because their ability to make choices is not recognized. In harmony with various discourses on equal opportunities and the right of self-determination in an inclusive society (Finnish National Core Curriculum for Basic Education, 2014, Nussbaum, 2006; UN, 2006), Taylor (2004) calls for "politics of recognition" when identifying discrimination in society. Indeed, "[o]ur identity is partly shaped by recognition or its absence, often by the misrecognition of others" (Taylor 2004, p. 25).

In special school settings ${ }^{1}$, agency is a complex process grounded in the intersections of individual growth, social interaction and the (lack of) recognition in the surrounding society. In this study, agency is understood as a capacity for individual action and decision-making in changing contexts, through which one adapts actions accordingly. Moreover, this capacity is embodied. Instead of committing to the Cartesian thought, where the body is separated from the mind, this study is inspired by the embodied mind paradigm (see e.g. Lakoff \& Johnson, 1999; Matyja \& Schiavio, 2013; Maes, 2016; Merleau-Ponty, 1962;). Thus, it emphasizes the mind-body unity as the core of cognition, consciousness, and learning (Sheets-Johnstone, 2009).

Following Campbell, Meynell and Sherwin (2009), we identify four aspects in the embodied notions of agency: subjectivity, intersubjectivity, emotions and autonomy (Juntunen, 2015; Sutela,

\footnotetext{
${ }^{1}$ Finland has invested significantly in developing a socially coherent system of basic education, which strives towards inclusion. General, intensified and/or special support is arranged to the pupils individually in local schools. However, the pupil will be transferred into a special education school if the local school or the region's special education group cannot provide sufficient support (Lakkala et al., 2019).
} 
Juntunen \& Ojala, 2019). Subjectivity is understood here not merely as psychological, but also embodied (Mackenzie 2009, p. 114) as we perceive, experience, act and engage in the world and with others in and through our bodies. Mackenzie's (ibid, p. 115) notion of "bodily perspective" depicts the dialectical relationship between body and subjectivity, highlighting how our engagement in the world is structured by our practical aims. Referring to Merleau-Ponty's (1962, p. 159) "I can" instead of "I think", Leder (1990) points out that the "I can" of the body and thus engagement with the world can be disturbed in a case of impairment. As the uniqueness of our body is the lens through which we plan for our actions, it affects our decision-making in our daily existence.

Agency is constituted through intersubjectivity, that is, "in and through one's lived bodily engagement with the world and others" (Mackenzie, 2009, p. 119). Agency is responsive to, and shaped by, the bodily realities and our individual history, including our relationships with others, and the social and cultural imagination (ibid., p. 121). The presence of impairment can reveal the extent to which individuals are interconnected. Disabled individuals can be treated as isolated rather than relational beings (see e.g., Ells, 2001). Emotions, in turn, prepare us to act (e.g., Damasio, 1994). They are our expressive attempts to make judgements of the world, helping us to direct our action, to develop ourselves, leading to autonomy (see e.g., Burrow, 2009; Maclaren, 2009). According to Lotan and Ells (2010, p. 114): "it is through our interactions with others in a supportive and encouraging environment that we learn the skills and gain the confidence necessary for autonomy". Thus, autonomy can be understood as a both embodied and socially constituted capacity, and it "can be impaired by abusive or oppressive interpersonal relationships and by social and political environments characterized by oppression, injustice, and inequality" (Mackenzie, 2008, p. 519).

In short, agency is manifested in and through future-oriented action and social-emotional engagement with others. Several studies suggest that students with special needs have difficulties in establishing meaningful relationships, thus facing a much greater risk of dropping out of school, leisure activities, work-life and society (Koster et al., 2010; Nepi et al., 2013; Robertson \& Cohen, 2017). Moreover, having few friends in school can negatively impact overall well-being with implications for motivation (Perdue et al., 2009) and may cause an extremely high risk of experiencing social exclusion in adulthood (Terzi, 2005). Several studies have indicated that participation in music provides opportunities for social bonding, self-determination and transition to community life (Adamek \& Darrow, 2012; Hammel \& Hourigan, 2011). According to Hove and Risen (2009) and Keller et al. (2014), musical synchrony can create social cohesion and increased affiliation. All this leads us to ask: How can music and movement enhance the development of agency for students with special needs?

In the context of music, the concept of agency has already for some time been approached by and debated among music education scholars (DeNora, 2010; Karlsen \& Westerlund, 2010; Karlsen, 2011; Laes, 2015). Additionally, research on how students with special needs can develop their agency in and through music education is almost nonexistent. Consequently, agency of special needs students is often unrecognized, forgotten or even denied also in (music) classrooms.

In this article we present an empirical study of the development of agency in students with special needs ${ }^{2}$ during an experiment of classroom music teaching in a special school. The Dalcroze

\footnotetext{
${ }^{2}$ By special needs we refer to sensory abnormalities and individual differences in sociability, behavior, concentration and learning. We are aware that the terminology on students with special needs is ethically challenging and may cause othering and further exclusion. As the students are not in a mainstream school, the descriptions of their behavior can
} 
approach is an example of music teaching practice that focuses on interactive student participation through body movement and experiential learning (Juntunen \& Hyvönen, 2004). Several studies suggest that Dalcroze-based music-and-movement teaching fosters social interaction and communication as well as develops awareness of personal identity and agency (e.g., Abril, 2011; Davidson, 2009; Juntunen, 2015; Sutela, Juntunen \& Ojala, 2019; Van Der Merwe, 2015). The therapeutic aspects of Dalcroze activities include a variety of possibilities to advance emotional understanding and foster social relationships (see e.g, Habron-James, 2013). This article aims to discover how the development of students' agency is supported in and through music-andmovement activities in music education.

\section{Methodology}

To examine the development of agency in students with special needs, we organized a teaching experiment during the school year 2015-16. This practitioner research (Cooper \& Ellis, 2011) was conducted in a lower secondary level special education school in northern Finland. Students $(\mathrm{N}=13$, 8 boys and 5 girls, one student left the school at the beginning of the school year and one declined to participate) were 15 to 16 years of age, from two different classes. The combined group consisted of diverse learners: many of the students had various neuropsychiatric symptoms. In addition to the students, two classroom teachers and their teaching assistants participated in the lessons and in the study.

Research ethics was addressed according to the standard procedures (Finnish Advisory Board on Research Integrity, 2012). Letters of information concerning the study were given to the students, their parents, the two participating teachers and the two teaching assistants. Signed informed consent forms were obtained from all the participants. In addition to the consent letters, the first author carefully explained the content and the course of action of the teaching experiment to the participants. She also provided information about the research weeks before the teaching experiment started and then again during the project. This notwithstanding, the question remains how to ensure that the students fully understand what they are consenting to. Furthermore, it was recognized that musicand-movement activities could evoke strong feelings, such as rage, joy, embarrassment, and sadness, and that those would need to be handled with the utmost discretion and care.

Weekly 45-minutes lessons, designed and given by the first author, included music-andmovement activities such as body percussion exercises, quick reaction and follow exercises, dramalike movement expression, dancing, and relaxation exercises. The teaching period was not designed to follow a preset plan, but evolved according to students' responses, their development and teacher reflections. The lessons took place in a large classroom, spacious enough for moving around. In order to activate the students both socially and bodily, the exercises included, for example, music listening with free expression of experiences through body movement, and body movement connected with the expression of perception or knowledge about musical phenomena (such as phrase length). The lessons followed the same basic structure each week, starting with an introduction in a circle and a warm-up exercise, followed by exercises related to the musical topic of the lesson, and finishing with relaxation. The musical topics included but were not limited to metrics, harmony and tempo. The

often be negatively charged, thus ignoring the positive aspects. The authors are describing the phenomenon here as the teachers and teaching assistants have expressed it and, in this study, sometimes negatively. This, in turn, may be telling about the workload that teachers and teaching assistants are facing in special education. 
main goals of the music-and-movement lessons were to lead students to trust their own ideas, to collaborate, and to help them discover their bodies as expressive instruments for agency.

The 21 lessons conducted from August 2015 to March 2016 were videotaped with one video camera for the analysis of interaction in the music learning environment, and to create an account of the development of agency (see e.g., Goldman et al., 2006). As subjectivity, intersubjectivity, emotions, and autonomy are not necessarily directly observable, we studied them indirectly via action and interaction. For a perspective on the subject's experience, the students were also interviewed, and the interviews were analyzed using thematic analysis (Attride-Stirling, 2001). However, during data production it became evident that the students struggled to verbalize in depth the development of their agency. Therefore, the video data and the observations by the teachers and the teaching assistants assumed a central role. The classroom teachers and teaching assistants were interviewed for their observations and conceptions of students' development. The observations and reflections of the participants (approximately 12 hours altogether) and of the teacher-researcher, as well as the research diary, were included in the analysis to enhance picture mainly drawn from the video data (approximately 16 hours total).

Based on familiarization with the video recordings of the lessons, we made initial coding for one student's actions and interactions during the teaching experiment using qualitative analysis software (NVivo). The coding was inspired by, but not similar to the one in Rainio's (2010) study: the initial data-driven codes consisted of bodily passivity, bodily activity, rambling, touching, bodily interaction, responsiveness, and initiative as indicators of the case student's agency. The codes concentrated on the student's interaction with others, his participation, initiatives and the ways of responding to others' initiatives in musical activities. For an analysis of the development of agency of all the students, we returned to initial coding, working further on coding as follows: 1) students' passivity (passive sitting, turning back, and following the lesson or something else on the side), 2) activity (moving according to the teacher's instructions or randomly), intersubjectivity (moving and participating through interaction with others), 3) interaction with objects (touching the walls, communicating with and through instruments, music, and other tools), 4) responsiveness (participating by responding to others initiatives by moving, nodding, or answering the questions) and 5) initiative (supporting, developing, contributing to or resisting others' suggestions and actions) as indicators of their agency. These codes were partly intertwined, as it was sometimes difficult to interpret students' actions. The coding revealed that most students' activity, intersubjectivity, responsiveness, and initiative increased towards the end of the school year. The expressions of the participants' actions were captured in the video recordings, but the meanings that the participants constructed were obviously not visible. Thus, the coding of the video data was used for conceptualization of what seemed to be essential when pursuing to understand how agency is manifested and possibly developed in music-and-movement activities and processes.

\section{Findings}

During the analysis process, we noticed that the students spontaneously formed groups: the "loners", and the separate units of the two girls and three boys. These subgroups were integrated in their acting and decision-making during the teaching experiment. To grasp the development of students' agency, it was important to pay attention to how their initiatives were developed further by others and to what degree they had any effect on the flow of the musical exercises. In what follows, we present the 
development of students' agency during the school year based on this grouping. For a timeline, see figure 1.

\section{$<$ FIGURE 1>}

\section{From individual obstacles to collective action}

Throughout the teaching experiment, six of the students were more or less on their own. Alex had challenges in behavior as he-continuously took initiative and space. However, he got along very well with everyone. In contrast, Beth, who had difficulties in social relationships, had been excluded in her own class because of her aggressive behavior towards classmates. Other students avoided her company, based on their previous experiences of her. Cathy also had challenging behavior and was thus also often rejected by her peers. While they were all active, they had difficulties in tolerating disappointments, which made them interrupt and disturb the flow of actions during the musical activities. It could be interpreted that their activity and interactivity often became unconstructive when they faced obstacles in their actions. On top of that, they tended to comment negatively on the exercises and actions by others, which did not help them to get accepted by the group. According to the reflections of the teacher and teacher assistant, Beth, just like Cathy, "did not really know how to be a friend, and caused all sorts of hassle just because not many want to be her friend, 'cause it's got to go on her terms" (Pauline, 22.9.2015). They needed to be supported by adults for their participation. Alex, in turn, was friendly towards the others, but often considered himself superior to them, causing confusion in the group. Initially, these three students were mainly aggressively active and responsive or, in Alex's case, hyperactive and often self-centredly motivated, and all three were therefore socially isolated from the others.

During the teaching experiment, they all learned to calm themselves down through musicand-movement exercises, which enabled them to concentrate on interaction with their peers and make constructive initiatives towards them. For example, the video data reveals how Alex, towards the end of the teaching experiment, was able to interact in and through musical exercises that were first rejected by him (Figure 2). He was also able to support others' ideas, be responsive to them, and wait for his turn. In Mackenzie's terms (2009, p. 115), his engagement in the musical exercises turned to be structured by his collectively constructive practical aims.

\section{$<$ FIGURE $2>$}

Similarly, Beth learned to calm herself down and to shift the focus gradually from subjective actions to collective ones. In the middle of the school year, she was able to express her creativity and skills through bodily movement, for example when bouncing a ball or playing the djembe in pulse and showing her example to other students. Furthermore, she performed musical exercises in pairs several times towards the end of the school year, which could be interpreted as her development in interaction. Moreover, she started taking initiative when asked to pair with her peer. The teaching assistant of her class described her development at the end of the teaching experiment: "music is what brings her that success and those experiences of succeeding ... that way, she got to really show her good sides and the abilities she has" (Tina, 5.4.2016). Music-and-movement activities supported 
Beth's expressive attempts to make judgements of the situation, helping her to direct her actions towards positive interaction with her peers (see e.g., Burrow, 2009; Maclaren, 2009).

In similar fashion, Cathy, who very much liked to dance, clearly enjoyed being recognized by the others, especially through the various dance movements she invented in front of them. At the beginning of the school year, she showed several deconstructive actions towards the musical activities. For example, she laughed at others' movements and spoiled shared exercises. Occasionally, she refused to be part of the lesson. However, her ways of approaching others changed from impulsive and self-absorbed to more sensitive and interactive. Her teacher described her actions at the end of the teaching experiment: "Cathy was more restrained and calmer" (Pauline, 12.4.2016). She became able to make initiatives towards her peers, changing her focus from herself to others. For Cathy herself, the independent decision-making and her sense of agency, the sense of "I can" (MerleauPonty, 1962, p. 159) in musical activities, came to play an important role in participation.

Well, yeah, I sort of like to move to music and so, but then if, like, you should be doing something the teacher tells you to, then it always goes to like me not taking part, but then, if I got to decide by myself what to do, then it was like different so that you're totally in it." (Cathy, 31.3. 2016)

In comparison, David, Ellen, and Noah were more introverted. At the beginning of the school year, they were shy, withdrawn and often passive in lessons. Ellen was a suspicious student who seemed to fear new situations and usually first refused to do an exercise or went away from the classroom. Rose, the teaching assistant of the class, pondered that Ellen may have sought attention through her behavior: "that way she got the attention that the girls here compete for" (Rose, 12.4. 2016). Noah, in turn, had already been diagnosed with autistic spectrum disorder, and largely lived in a world of his own having lots of challenges in communication and interaction ${ }^{3}$. At first, these three students manifested passivity in new situations. This was apparent, for instance, in the video data, where Ellen and Noah literally walked away from new learning situations and sat passively on the side. The following excerpt shows an example of this kind of a situation, ending up with Ellen returning and participating again, after all:

We are doing an exercise in which we walk around the room to the beat of music, throwing a soft toy to each other. Ellen participates fully, and she knows from whom to catch the toy and to whom to throw it while moving. Suddenly I shout: "Hi, dj, stop the music! And please come here all!" At the same time, Ellen walks away from the room. Others don't see that. I start to give new instructions to change the direction of toy throwing. When it is Ellen's turn, we notice that she has disappeared. "Ellen!", Pauline shouts and goes to look for her. The exercise is interrupted, and we are waiting for Ellen. After a while, Ellen comes back and decides to stay out of the exercise. After watching others doing the exercise for a minute, she walks to Pauline and says her ankle and neck are hurting. However, she is soon participating in the exercise again. (Videotape transcription of musicand-movement lesson, 5.11.2015)

During the teaching experiment, these three students needed, and were given, constant support by adults in their actions. In a way, they had difficulties in committing to the exercises. However, especially Noah's and David's agency developed during the teaching experiment through the musical activities. Noah changed from a passive outsider to an active participant and even leader, as he learned to communicate through non-verbal, embodied ways in music. His agency was manifested in his embodied capacity to act in and through music with others. The change in his agency development was also noticed outside the classroom: he started to take initiative and interact with others. ${ }^{4}$

\footnotetext{
${ }^{3}$ Permission to use Noah's diagnosis was granted. It helps to better understand the challenges he had in interaction and participation, or in agency in general.

${ }^{4}$ The case of Noah's development is examined and analyzed in closer detail in Sutela, Juntunen \& Ojala (2019).
} 
Noah immediately noticed that "hey, here's a sledge and a child on it, and a rope, and this needs someone to pull it" - and joined the play. And afterwards, people in the teachers' lounge were astonished that one day someone came over to say that "Come, look, Noah's there pulling that child". [...] Noah's participation has increased by 500\%. At least. What happened with Noah was that first his gaze changed, to the kind that he sought attention, and every now and then peeked from there. And then he came out into the open, [showing] that

"I am here". And then his participation in the intermission activities. It's really amazing. (Sarah, 5.4.2016)

David actively began to pursue to participate in everything, despite his many challenges in learning and motor skills. He was active and responsive, but lacking initiative in decision-making. For David, the turning point in the development of his agency took place on October 29th, when the teacherresearcher had problems with the internet connection in preparation for the lesson and with the music she was using. David volunteered to help her with his own phone. After that, he became responsible for music playing in the lessons. The next excerpt depicts the situation:

We are gathering together to start the lesson. David comes to me and hugs me, saying: "Wasn't it good that I could help you?" "Yeah, thank you - I was totally lost", I answer. "You don't understand anything about information technology, do you?", he continues. "No, I don't", I laugh. (Videotape transcription of music-andmovement lesson, 29.10.2015)

From this event on, he turned from a passive and rarely responsive student to an active DJ, who wanted to choose the music for some of the exercises. He found his own way of taking responsibility in the lessons, and through interconnectedness with the teacher-researcher he gained the confidence necessary for individual acts (Lotan \& Ells, 2010, p. 114). As far as Ellen's agency is concerned, there was no notable development during the school year. She continued to disappear during new turns in the lesson and only participated occasionally. However, she took initiative towards the teacher-researcher and her peers at the end of the teaching experiment. It seems the she would have benefited from a longer period of music-and-movement teaching.

Among these six students, the challenge was how they could adjust their own decision-making to that of others. At the beginning of the school year, many of them manifested their agency (or lack thereof) by turning or walking away, by refusing to participate, by resisting or by negatively affecting the interaction in musical exercises by interrupting the flow of the exercises or making initiatives in musical activities. Some of these manifestations of agency restricted their possibilities for interaction and further actions in the class. The teachers and teaching assistants performed musical exercises with these "loners" in pairs, encouraging them to try new things and helping every student to achieve their highest level of participation. This support helped them to practice their bodily skills - and through them, their social skills - safely, and thereby to "gain the confidence necessary for autonomy" (Lotan \& Ells, 2010, p. 114). This was manifested, for example, in their increased ability to finally perform musical activities alone or as a student-student pair. The exercises activated their selfregulation and invited them to act and interact with others. As Sarah (the teacher of the $9^{\text {th }}$ grade) reflected on their increased participation during the lessons, the students no longer feared each other so much.

In my opinion, toleration within that group has grown, at least in some ways, very delicately. That they, just like [with] that trust, that they are not so afraid of one another. And that their joint experience also has unified them in a way. So there has been, between the two groups, [...]clearly some fearfulness towards some students, but we've got rid of it a little. (Sarah, interview, 5.4.2016)

Creation of one's own world in the music-and-movement lessons 
Gaby and Holly were already good friends with each other before the teaching experiment. They were kind girls who did everything as asked, never questioning or resisting teachers' instructions or causing any harm. They were always paired, sitting next to each other, and holding hands. In a sense, they created a private space of their own where there was no room for others. In comparison to other students, the girls were quite invisible to the participating adults to the point that the teacher and teaching assistants barely mentioned them in the interviews.

The video data showed that the girls' movements in the musical exercises were mainly small and limited and turned inwards or towards each other (Figure 3). In a way, Gaby and Holly were active and responsive in the lessons, as they followed the instructions given, but still, passive in relation to the other participants and their initiatives. In a way, their agency was responsive to and shaped by their relationship with each other.

\section{$<$ FIGURE 3 >}

Towards the end of the teaching experiment, the girls showed small signs of reaching out to others. For example, in an exercise where the students were instructed to make pairs in the group of students according to what they heard in music, Gaby reached her hand towards Noah, who was shy and, at that point, still unable to make an initiative when choosing pairs. Similarly, Gaby did not turn away from Cathy, who wanted to have a conversation with her at the beginning of one lesson. The next excerpt describes the situation:

We are about to start the lesson. Isaac is improvising with the piano and I am gathering my things in order to get started with teaching. Some students are walking around, some are sitting and waiting. Cathy and Gaby are walking and talking to each other, while Holly is undressing her outdoor clothes. Gaby turns towards Cathy, talks and listens to her, until Holly comes to pick Gaby up. They hold each other by the hand and Cathy walks away from them. (Videotape transcription of music-and-movement lesson, 18.2.2016)

This was the first time Gaby showed any activity towards Cathy during the teaching experiment. Gaby and Holly were so bound together that there had been no room for others. Especially, Holly was dependent on Gaby in her actions. However, in an exercise where everyone showed a movement pattern for others to follow, Holly was active and showing her willingness to be the first to show hers: We are in a circle, and after the first round of movements, I say: "Hey, let's take one more round where those who want to show a new movement, do it!". I turn away and go to pick up Noah, who is standing behind Isaac and at the same time Holly walks and shows her movements, raising hands high and whirling around. Others follow her and she laughs when watching them. (Videotape transcription of music-and-movement lesson, 11.2.2016)

All in all, the accumulated data gave little evidence of any development in their agency. Gaby and Holly had their own world within the lessons, which isolated them from the others. They did break out of it when asked, but always "bounced back" and resorted to their own safe space. They were active and responsive within their own world. In addition to this, their limited movements, gestures and restrictive postures expressed "a femininity of compliance" (Burrow, 2009, p. 126), and thus, decreased their chances for action and self-expression. Their passive, restricted bodily movements may represent how they were in fact undermining their own agency in comparison to the physically bigger students demanding more space. Gaby's and Holly's self-motivated initiatives and interactivity in the group started to manifest at the very end of the teaching experiment. However, they would have needed more time and more scaffolding to further adjust their own actions to those of others in a group. 


\section{From collective resistance to individual decision-making}

Akin to the girl duo, the group of three ${ }^{5}$ boys Isaac, Jim, and Kenny, did everything together in the lessons. They were from the same class, always sat next to each other, and performed all the exercises together, if not instructed otherwise. When the teacher-researcher gave instructions to the class, they turned to each other to get a mutual confirmation of how to react and respond to the instructions. Isaac was an exception: he occasionally had the courage to resist the joint decision-making.

At the beginning of the school year, they expressed their agency through collective resistance, for example by performing musical exercises together but apart from the others, collectively resisting the teacher-researcher's instructions, interrupting or slowing the flow of the exercise (for example, by bouncing the ball too hard for others to catch it). Their interaction was mainly focused on their own faction, and not on others in the group. Like Gaby and Holly, they were responsive and took initiative within their own sphere, but not much outside of it. They were allowed to improvise the exercise by themselves, in case they showed strong resistance or passivity toward the instructions. Especially Jim showed active resistance to many exercises, trying to lure Isaac and Kenny to join him by turning his back, laying down on the floor or whispering to them. Being the tallest of the trio, Jim captured the space with his big and masculine movements. The trio reported that early morning and their tiredness were the reason for their refusal in some musical activities: "Well, hmm, sometimes [I] felt a little tired and kinda often just didn't have the energy to do [the exercises] then. I did listen to what was said, though." (Jim, 31.3. 2016.) They decided the level of their participation themselves, often led by Jim. Their classroom teacher interpreted the students' resistance as a process of independence or fear of failure:

Some of them showed some contradiction in that they also wanted to bring forward their need to become independent and grow up... what might be behind this questioning might basically be some kind of inability to function for some reason. Then [there could be] some incapacity, fear of failing and low self-esteem. (Sarah, 5.4.2016)

Little by little, Kenny started to show resistance to the trio's collective decision-making: "Kenny clearly would like to do the exercises, but because the other boys don't participate, he just stands there for a moment, arms crossed, and doesn't know what to do." (Research diary 1.10.2015). Gradually, his bodily position changed, and he opened up himself - both physically and socially towards the others, as if waiting for an invitation to join the musical activities. He began manifesting his agency through his embodied and social capacity to act and interact. Gradually, he became more active, stronger with his self, started making individual decisions, often resisting especially those by Jim. The changes in Kenny's agency affected Isaac and Jim, as well: "Jim and Isaac try to cop out every now and then, but Kenny is actively with us and clearly gets Isaac and Jim to stay with us as well." (Research diary, 29.10.2015.) As the teaching experiment progressed, Kenny participated more actively in musical exercises and interacted with other students. He also started to move in more open ways, while his bodily stance and movements had been very limited at the beginning.

Following Kenny, Isaac, who had been strong in his decision-making from the beginning (if he wanted), also started to be more active and take initiative in the lessons. For example, he accompanied one relaxation exercise with the piano and led a chain dance. Moreover, he started to develop the musical exercises further by developing movements and gestures, and improvising

\footnotetext{
${ }^{5}$ At the beginning, they were four, but one student left the school after a few lessons.
} 
"stories" within drama exercises, and thus, being interactive outside of their trio, exhibiting autonomous agency.

We are performing and exercising in pairs to develop kinesthetic awareness. In the exercise, one participant acts as a marionette, while the other one moves the marionette by pulling the imaginary strings attached to the joints. It is Isaac's and Kenny's turn to perform their marionette to the others. Kenny starts to pull imaginary strings attached to Isaac. However, Isaac takes control over Kenny and "comes alive". He starts to move around the "stage" and Kenny runs after him. Everyone is laughing as Isaac performs his marionette coming alive. (Videotape transcription of music-and-movement lesson, 18.2.2016)

Isaac also began to show his newly developed skills actively in singing and dancing. His agency was manifested in his autonomous and constructive acting in musical exercises. Finally, towards the end of the teaching experiment, Jim started to show some initiative. For example, he led the chain dance (Figure 4). He also contributed to the drama exercise. Still, he stayed mainly passive and his attitude towards the musical exercises was often negative even at the end of the experiment. He decided to manifest his agency through negative attitudes and resistance.

\section{$<$ FIGURE 4 >}

\section{Discussion}

For those who participated actively, the teaching experiment offered a platform to exercise their individual decision-making, interaction, expression of their knowledge and musicianship. Based on the interviews and the research diary, the music-and-movement exercises, with turn-taking, listening to music and responding to it with movements, improvisation and interactional nature of those exercises, created a safe sphere for the development of agency. For others, the time period was insufficient but promising, referring to the forms of incipit agency (Metcalfe \& Terrace, 2013).

In sum, students were perceiving, acting, and experiencing the music and others in the lessons through their bodies, and thus, highlighting the embodied nature of their subjectivity. Their decisionmaking and interaction were structured by their practical aims when engaging in musical exercises with others. Active participation in musical exercises in pairs and in groups supported the participants' activity in relation to others, that is, their intersubjectivity. As Lotan and Ells (2010, p. 114) note, "as opposed to freedom from others, a relationship with others is a precondition for autonomy (emphasis added)". For many students, moving to the music they heard, singing, and playing face to face with teachers and teaching assistants was not only a step towards more independent actions, but also a step to learn interaction with peers. These positive interactions and emotional support from others promoted their engagement in the musical activities (see also Juntunen, 2015). These shared acts of trust within musical activities diminished the "asymmetrical power" (Lotan \& Ells, 2010, p. 116) of who is able and who is not, as the musical knowledge was expressed through shared movements (for example, open gesture to a major chord and closed gesture to a minor chord) and mutual recognition. However, some of the students would have needed more time for increased trust in their peers.

The students' activity in the lessons was affected by the bodily cues (emotions, voices, gestures) of others (Hoehl, 2013; Metcalfe \& Terrace, 2013). Their expression of emotions often seemed to function as a catalyst for their actions during the teaching experiment. For example, if a student was in a bad mood, (s)he refused to participate, or walked away, turned their back, etc. On 
the contrary, emotions of joy were expressed in quite the opposite way: by coming close to others, participating fully, and expressing larger movements. In consequence, the students were adjusting their own action to that of others, and emotional cues and expressions affected their decision-making in musical interaction. Hence, the students negotiated their subjectivity with that of the others. If the world appeared strange to the students, or they were unable to get a response to their bodily expressions, the intentionality of their actions was oriented inwards, that is, to themselves, objects, or other individuals close to them. The students could be responsive to the world, but unable to make initiatives or contribute to the flow of actions. When the world appeared as something safe and encouraging, they acted outwards, contributing to the flow of actions and making initiatives in them, and thus, manifesting and developing their own individual agency.

The analysis indicates that the development of agency is indeed enabled or prevented on three intertwined levels: 1) on an individual level, where we recognize our self and its possibilities 2) on a social level, where our agency is (mal)formed through the interaction with others, and 3) and on a societal level, where the politics define if we are seen as capable agents in society. The individual level and the social level are in a constant dialogue, through which agency is (mal)formed, depending on whether the dialogue is supportive or deconstructive. That is, if the students do not get support for their initiatives in music classroom, it is difficult for them to see themselves as capable musicians. Regardless of the school system per se, the development of agency is enabled by equal access to and sufficient support for learning - issues guided by the societal structures - and, based on this study, by the participation in music-and-movement education in particular.

Based on these findings, we propose that music and movement should be considered more widely as a meaningful way of learning music and developing agency, at least with students with special needs. We want to challenge educators to consider music and movement as a tool, through which equal learning practices may facilitate learners to "grow into active citizens by developing knowledge and skills for operating in a democratic, egalitarian society" (Ministry of Culture and Education, 2014, p. 18). Music-and-movement activities (such as body percussion, lead and follow, quick response, moving to the music exercises) can enable the individuals to develop their bodily skills, confidence, communication, self-awareness, and autonomy. Thus, we suggest that music-andmovement activities are applicable in special education by enabling students with different needs to exercise agency and to achieve empowerment, thus giving them tools to become active members of society.

However, there are challenges that the teacher should be aware of before applying music and movement in a special school. Students can be unsure of themselves and it may take time to win their trust. On top of that, a group of diverse learners can make music teaching vulnerable to students' behavioral challenges. Therefore, flexible pedagogical structures and long-term scaffolding of these kinds of pedagogical working habits are needed. However, the structures of the exercises within the lessons are important. Many students have experiences of being bullied, so the musical exercises must be planned with due respect for their own personal space and growth, focusing on the importance of a safe atmosphere. Needing support in learning, communication and motor skills, the teacher has to plan the lessons in ways that enable everyone's participation. Similarly, when executing processes based on imagination some students may have difficulties in separating the imagined and reality. Thus, the exercises must be followed by reflection, and different experiences and sensations must be addressed with respect and care. 
Although the issues of students with special needs and their active participation (see Laes, 2017) have been increasingly addressed in multi-disciplinary academic research, there is still a need for further research on how music education supports the development of each individual's agency in society. By recognizing the equal value of different learners in music classrooms, we acknowledge their worth as full members of the society.

\section{Declaration of interest statement}

The authors declare no conflicts of interest.

\section{References:}

Abril, C. R. (2011). Music, movement, and learning. In R. Colwell \& P. R. Webster (Eds.), The MENC handbook of research in music learning, Volume 2: Applications (pp. 92129). New York: Oxford University Press.

Adamek, M., \& Darrow, A.-A. (2012). The intersections of arts education and special education: Exemplary programs and approaches. Music participation as a means to facilitate self-determination and transition to community life for students with disabilities. Washington, DC: The Kennedy Center. http://education.kennedycenter.org/education/vsa/resources/FinalprofessionalpapersbookArticle6.pdf

Attride-Stirling, J. (2001). Thematic networks: An analytic tool for qualitative research. Qualitative Research 1(3), 385-405.

Basic Education Act 628/1998. Amendments up to 1136/2010. (2010). Government of Finland. Burrow, S. (2009). Bodily limits to autonomy: Emotion, attitude, and self-defense. In S. Campbell, L. Meynell \& S. Sherwin (Eds.), Embodiment and agency (pp. 126-144). University Park: The Pennsylvania State University Press.

Campbell, S., Meynell, L., \& Sherwin, S. (2009). Embodiment and agency. University Park: The Pennsylvania State University Press.

Cooper, V., \& Ellis, C. (2011). Ethnographic practitioner research. In S. Callan \& M. Reed (Eds.), Work-based research in the early years: Positioning yourself as a researcher (pp. 47-61). London: Sage.

Damasio, A. R. (1994). Descartes' error: Emotion, reason and the human brain. New York: HarperCollins.

Davidson, J. W. (2009). Movement and collaboration in musical performance. In S. Hallam, I. Cross \& M. Thaut (Eds.), Oxford handbook of music psychology (pp. 364-376). Oxford: Oxford University Press.

Davis, J., \& Watson, N. (2000). Disabled children's rights in everyday life: Problematising notions of competency and promoting self-empowerment. The International Journal of Children's Rights, 8(3), 211-228.

DeNora, T. (2002). Music in everyday life. Cambridge: Cambridge University Press.

Ells, C. (2001). Lessons about autonomy from the experience of disability. Social Theory and Practice, 27(4), 599-615. 
Finnish Advisory Boeard on Research Intergrity. (2012). Responsible conduct of research and procedures for handling allegations of misconduct in Finland. Finnish Advisory Board on Research Integrity. http://www.tenk.fi/sites/tenk.fi/files/HTK_ohje_2012.pdf

Goldman, R., Pea, R., Barron, B., \& Denny, S. J. (2006). (Eds.) Video research in the learning sciences. New York: Routledge.

Habron-James, B. (2013). Mémoire de Diplôme: The application of Dalcroze Eurhythmics to the teaching of children with special educational needs. Unpublished Diplome Superieur thesis, Institut Jaques-Dalcroze, Geneva.

Hammel, A. M., \& Houringan, R. (2011). Teaching music to students with special needs: A labelfree approach. New York: Oxford University Press.

Hoehl, S. (2013). Early sensitivity to emotion cues: Precursors of social referencing? In J. Metcalfe \& H. S. Terrace (Eds.), Agency and joint attention. (pp. 196-205) New York: Oxford University Press.

Hove, M. J., \& Risen, J. L. (2009). It's all in the timing: Interpersonal synchrony increases affiliation. Social Cognition, 27, 949-961.

Juntunen, M.-L., \& Hyvönen, L. (2004). Embodiment in musical knowing: How body movement facilitates learning with Dalcroze Eurythmics. British Journal of Music Education, 21(2), 199-214.

Juntunen, M.-L. (2015). Pedagoginen kokeilu integroida Ipadin käyttö, luova tuottaminen ja keholliset työtavat peruskoulun seitsemännen luokan musiikinopetuksessa: Tapaustutkimus toimijuuden näkökulmasta [Pedagogical experiment on the use of iPads with creative production and bodily approaches in $7^{\text {th }}$ grade music instruction: A case study from the perspective of agency]. Finnish Journal of Music Education, 18(1), 56-76.

Juntunen, M.-L. (2016). The Dalcroze approach: Experiencing and knowing music through the embodied exploration. In C. R. Abril \& B. Gault (Eds.), Approaches to teaching general music: Methods, issues, and viewpoints (pp. 141-167). Oxford: Oxford University Press.

Karlsen, S. (2011). Using musical agency as a lens: Researching music education from the angle of experience. Research Studies in Music Education, 33(2), 107-121.

Karlsen, S., \& Westerlund, H. (2010). Immigrant students' development of musical agency: Exploring democracy in music education. British Journal of Music Education 27(3), 225-239.

Keller P. E., Novembre, G., \& Hove, M. J. (2014). Rhythm in joint action: Psychological and neurophysiological mechanisms for real-time interpersonal coordination. Phil. Trans. R. Soc. B 369: 20130394.

Koster, M., Timmerman, M. E., Nakken, H., Pijl, S. J., \& van Houten, J. E. (2009). Evaluating social participation of pupils with special needs in regular primary schools. European Journal of Psychological Assessment 25(4), 213-222.

Laes, T. (2015). Empowering later adulthood music education: A case study of a rock band for third-age learners. International Journal of Music Education Research 33(1), 51-65. doi: $10.1177 / 0255761413515815$ 
Laes, T. (2017). The (im)possibility of inclusion: Reimagining the potentials of democratic inclusion in and through activist music education. Studia Musica 72. Helsinki: Sibelius-Akatemia.

Lakkala, S., Miettunen, H., Takala, M., Kyrö-Ämmälä, O., Sarivaara, E., Kielinen, M. (2019). Steps towards and challenges of inclusive education in Northern Finland. In M.C. Beaton, D.B. Hirshberg, G. R. Maxwell \& J. Spratt (Eds.), Including the north A comparative study of the policies on inclusion and equity in the Circumpolar North (pp. 125-142). Retrieved from: http://urn.fi/URN:ISBN:978-952-337$\underline{136-1}$

Lakoff, G. \& Johnson, M. (1999). Philosophy in the flesh: The embodied mind and its challenge to western thought. New York: Basic Books.

Leder, D. (1990). The absent body. Chicago: The University of Chicago Press.

Lotan, G., \& Ells, C. (2010). Adults with intellectual and developmental disabilities and participation in decision making: Ethical considerations for professional-client practice. Intellectual and Developmental Disabilities, 48, 112-125. doi:10.1352/ 19349556-48.2.112

Mackenzie, C. (2009). Personal identity, narrative integration, and embodiment. In S. Campbell, L. Meynell \& S. Sherwin (Eds.), Embodiment and agency (pp. 100-125). University Park: The Pennsylvania State University Press.

Maclaren, K. (2009). Emotional metamorphoses: The role of others in becoming a subject. In S. Campbell, L. Meynell \& S. Sherwin (Eds.), Embodiment and agency (pp. 2545). University Park: The Pennsylvania State University Press.

Maes, P.-J. (2016). Sensorimotor grounding of musical embodiment and the role of prediction: A review. Front Psychology, 7, 1-10.

Matyja, J. R., \& Schiavio, A. (2013). Enactive music cognition: Background and research themes. Constructivist Foundations 8(3): 351-357.

Merleau-Ponty, M. (1962). Phenomenology of perception. London: Routledge.

Metcalfe, J., \& Terrace, H. S. (Eds.). (2013). Agency and joint attention. New York: Oxford University Press.

Ministry of Education and Culture. (2014). Teacher education in Finland: Leaflet 1. Retrieved from: http://www.oph.fi/download/154491_Teacher_Education_in_Finland.pdf

National Board of Education. (2014). National Core Curriculum for Basic Education. Helsinki

Nepi, L. D., Facondini, R., Nucci, F., \& Peru, A. (2013). Evidence from full-inclusion model: The social position and sense of belonging of students with special educational needs and their peers in Italian primary school. European Journal of Special Needs Education 28(3), 319-332.

Nussbaum, M. C. (2006). Frontiers of justice: Disability nationality species membership. Cambridge, MA: Belknap Press of Harvard University Press.

Perdue, N. H., Manzeske, D. P., \& Estell, D. B. (2009). Early predictors of school engagement: Exploring the role of peer relationships. Psychology in the Schools 46(10), 1084-1097. doi: 10.1002/pits.20446.

Rainio, A. P. (2010). Lionhearts of the playworld: An ethnographic case study of the development of agency in play pedagogy. Helsinki: University of Helsinki, Institute of Behavioural Sciences. Studies in Educational Sciences 233. 
Robertson, C. E., \& Baron-Cohen, S. (2017). Sensory perception in autism. Nature Reviews.

Neuroscience, 18, 671-684.

Sheets-Johnstone, M. (2009). The corporeal turn: An interdisciplinary reader. Exeter: Imprint Academic.

Taylor, C. (1994). The politics of recognition. In A. Gutmann (ed.) Multiculturalism: Examining the politics of recognition (pp. 25-73). Princeton, NJ: Princeton University Press.

Terzi, L. (2007). Capability and educational equality: The just distribution of resources to students with disabilities and special educational needs. Journal of Philosophy of Education, 41(4), 757-773.

UN (United Nations). (2006). Convention on the rights of persons with disabilities. New York: The United Nations.

Unesco. (2003). Overcoming exclusion through inclusive approaches in education: A challenge and a vision. Conceptual paper. Retrieved from http://unesdoc.unesco.org/images/0013/001347/134785e.pdf

Van der Merwe, L. (2015). The first experiences of music students with Dalcroze-inspired activities: A phenomenological study. Psychology of Music, 43(3), 390-406.

Wehmeyer, M. L., \& Palmer, S. B. (2003). Adult outcomes for students with cognitive disabilities three-years after high school: The impact of self-determination. Education and Training in Developmental Disabilities, 38(2), 131-144. 